\title{
A Brief Overview of Literacy studies and Education in Brazil
}

\author{
Ana Elisa Ribeiro ${ }^{1}$ and Carla Viviana Coscarelli ${ }^{2}$ \\ ${ }^{1}$ Federal Centre of Technological Education of Minas Gerais, Brasil \\ ${ }^{2}$ Federal University of Minas Gerais, Brasil
}

doi: https://doi.org/10.7358/ijtl-2017-004-ribe

anadigitalpro@gmail.com

cvcosc@gmail.com

ABSTRACT - In this paper, we present a brief overview of literacy and multiliteracies studies in Brazil, in particular research dealing with the relationships among reading, text production, multimodality, media and education. We also present comments on the results of recent research on literacy skills of the Brazilian population, such as the National Indicator of Functional Literacy and the National Examination of Secondary Education. We conclude arguing that those who work in Brazilian education and literacy practices still have a long way to go until they manage successful practices to improve and foster literacy widely.

\section{INTRODUCTION}

The concept of 'literacy' has been widely discussed in Brazil for about three decades now, mainly under the influence of pioneering researchers such as Brian Street in England and the New London Group in the United States during the 1990s. In these thirty years, alongside the discussion on the difference, in Portuguese, between the concepts of 'alphabetizing' and 'literacy', other derivatives have emerged, leading to different notions, such as literacies (plural), adjectivated literacies (digital, information, resistance, academic, visual, etc.), multiliteracies, Hypermultimedia literacy, among others. This trajectory of studies and debates allows us to say that Brazil has been producing knowledge about its own education, alphabetization and literacy, managing the tools available, generating knowledge that impacts internal public policies as well as knowledge that impacts the development of research in the fields of Applied Linguistics and Education.

International Journal of Transmedia Literacy - 3 - December 2017

http: //www.ledonline.it/transmedialiteracy - Online ISSN 2465-2261 - Print ISSN 2465-227X 
The concept of "transmedia literacy" is not widely widespread in the country, but debates on multimodality, intermedia, among other concepts that take emphatically into account media and its connections, are emerging in connection to both reading and writing. Literacy issues can be found mainly in the fields of education and applied linguistics, while the fields of literary and media studies have been discussing other issues like 'transmediality', based on Henry Jenkins's (2006) work, 'intermediality' following the work, among others, of Elleström (2009), and 'remediation', as proposed by David Bolter and Richard Grusin, (2000), each strand having its own aims and objects.

Considering the experience gathered in this scenario, we intend to offer in this paper a brief overview of recent Brazilian studies on literacy, mainly in the field of applied linguistics, which has promoted broad discussions about teacher development, education and meaningful use of Information and Communications Technologies (ICTs) in the context of reading and writing skills' development.

\section{LITERACY RESEARCH IN BRAZIL TODAY}

The Parâmetros Curriculares Nacionais (PCN - National Curricular Parameters) were published in 1997 (Brasil 1997). It is the official document that guides the Brazilian school network. Since early 1990s, this document has acknowledged the need for school to work within a critical literacy perspective and to consider the contribution of language studies to the development of citizenship. In addition, it argues that the education system should be

an educational practice adequate to the social, political, economic and cultural needs of the Brazilian reality, that considers the interests and motivations of the students and guarantees the essential learning for the formation of autonomous, critical and participative citizens able to act with competence, dignity and responsibility in the society in which they live. (Abreu et al. 1997, 27)

This perspective also includes the idea of incorporating technologies in constant renovation, thus preparing students to foster new skills that will enable them to deal with these changes at best. 
It is not enough to aim at preparing students for future abilities in terms of traditional specialties, but it is rather necessary to prepare students to acquire and develop new skills, due to the new kind of knowledge that is produced and that demands a new professional figures, who need to be able to deal with new technologies and languages, and capable of responding to new rhythms and processes. (Abreu et al. 1997, 28)

Aligned to the NCPs, there is an effort in Brazil to evaluate students' reading skills at various stages of their education. Large-scale assessments, such as Saeb (Basic Education Assessment System) and the Enem (National High School Evaluation), were created and implemented.

SAEB was introduced in 1990. Although it is concerned with social aspects of language, it chiefly emphasizes individual reading skills, by measuring and assessing what the student can do with the text, while, at the same time, overlooking aspects related to the social uses of language. For instance, among other abilities the students' ability to infer the meaning of a word in a given text is evaluated, or also the ability to discern primary and secondary sections, in term of importance and information value, of the text from secondary ones (Bonamino, Coscarelli and Franco 2002, 100).

One criticism of Saeb is that it does not explore in depth the huge textual diversity that circulates in our society, being restricted to the most common texts found in print didactic materials, such as poems, short stories or chronicles, advertisements, comics, news and reports (from press newspapers and magazines).

We can say, therefore, that this evaluation, albeit raising valuable data about reading skills of Brazilian students, does not directly assess their reading competence (and, by consequence, their literacy), since their ability to deal with several texts of our daily life is not directly evaluated in SAEB (Bonamino, Coscarelli, Franco 2002, 100)

Enem, in turn, "was created in 1998 with the purpose of evaluating students' performance when concluding basic education" (Ministério da Educação. Instituto Nacional de Estudos e Pesquisas Educacionais Anísio Teixeira, n/a). Its matrix of skills consists of six common axes for each knowledge area evaluated (Mathematics and its technologies, Human sciences and their technologies, Languages, codes and their technologies, and Natural sciences and their technologies). These areas theoretically align to the PCN, as far as the development of citizens able to respond to the de- 
mands of our society is concerned. The axes are:

1. Mastering languages: mastering standard Portuguese and making use of mathematical, artistic and scientific languages as well as Spanish and English

2. Understand phenomena: building and applying concepts of different areas of knowledge to understand natural phenomena, historicalgeographical processes, technological production and artistic manifestations.

3. Solve problems: select, organize, relate, interpret data and information represented in different ways, in order to make decisions and deal with challenging situations.

4. Build arguments: correlate assorted information, as well as available knowledge in concrete situations, in order to build a consistent argumentation.

5. Elaborate proposals: use knowledge gained in school for elaborating proposals for social intervention in real life, respecting human values and considering socio- cultural diversity.

Enem is clearly concerned with a broad conceptualization of students' development, including social aspects. This concern is revealed in skills related to solve problems, to elaborate proposals of solidarity, and to respect socio-cultural diversity. The presence of these aspects in this evaluation complies with the perspective of multiliteracy (García-Canclíni 2001, 2008; Rojo and Almeida 2012). According to Rojo and Almeida (2012, 13), "the concept of multilevels points to two specific and important types of multiplicity found in our contemporaneous societies, especially urban ones: the cultural multiplicity of populations and the semiotic multiplicity used to build texts."

Although, as far as the area of languages and its technologies is concerned, the focus of Enem is to assess the domain of standard Portuguese language, we also notice the stress on linguistic variants and their adequate use in different situations within the whole matrix of skills (as the topic 25 Identify, in texts of different genres, linguistic marks that distinguish social and regional linguistic varieties and the topic 26 - Correlate linguistic varieties to specific situations of social use). It should be remarked, however, that situations demanding the recognition or identification of linguistic variants are more emphasized than their actual use, since, for example, the use of variants other than the standard one is not allowed in the written parts of the exam. Another skill that is compatible with a multiliteracy 
perspective can be found at the Human Sciences matrix of skills: "using historical knowledge to understand and value the foundations of citizenship and democracy, promoting conscious actions of the individual in society" (Ministério da Educação. Instituto Nacional de Estudos e Pesquisas Educacionais Anísio Tei-xeira, n/a).

Despite valuing technology - as the presence of the word 'technologies' in the titles of each area of the evaluation attests - its use, and more specifically the use of ICTs, is still deficient. The matrix of skills evaluated stimulates the following ability: "to apply communication and information technologies in school, at work and in other contexts relevant to their life" (Ministério da Educação. Instituto Nacional de Estudos e Pesquisas Educacionais Anísio Tei-xeira, n/a). However, it is very difficult to assess this skill in a multiple-choice test. National assessments matrix of skills usually guide curriculum and school practices; and yet, data from other projects, such as INAF (National Indicator of Functional Literacy) and PISA (Programme for International Student Assessment), reveal that Brazilians still struggle when dealing with texts, especially complex and multimodal ones.

Data collected by INAF, for example, show that we still have a high number of illiterate people in the population between 15 and 64 years of age. Only $26 \%$ of the population can be considered fully literate, referring by this to "people whose abilities no longer impose restrictions to understand and interpret texts in usual situations: read longer texts, analyze and relate their parts, compare and evaluate information, distinguish fact from opinion, make inferences and synthesizing" (Lima et al. 2016, 2).

Regarding the use of ICTs, according to INAF the number of computer users has increased over the years, as well as the amount of time people spend using computers, mainly at home and at work ${ }^{1}$. These data also allow us to know what people do with computer (Figure 1).

${ }^{1}$ Brazilian Institute of Geography and Statistics (IBGE) has just released a survey on the Brazilian population. One of the results points to the decreasing use of desktop computers due to the increase of the use of mobile devices for various everyday activities. (IBGE, 2016)

International Journal of Transmedia Literacy - 3 - December 2017

http: //www.ledonline.it/transmedialiteracy - Online ISSN 2465-2261 - Print ISSN 2465-227X 


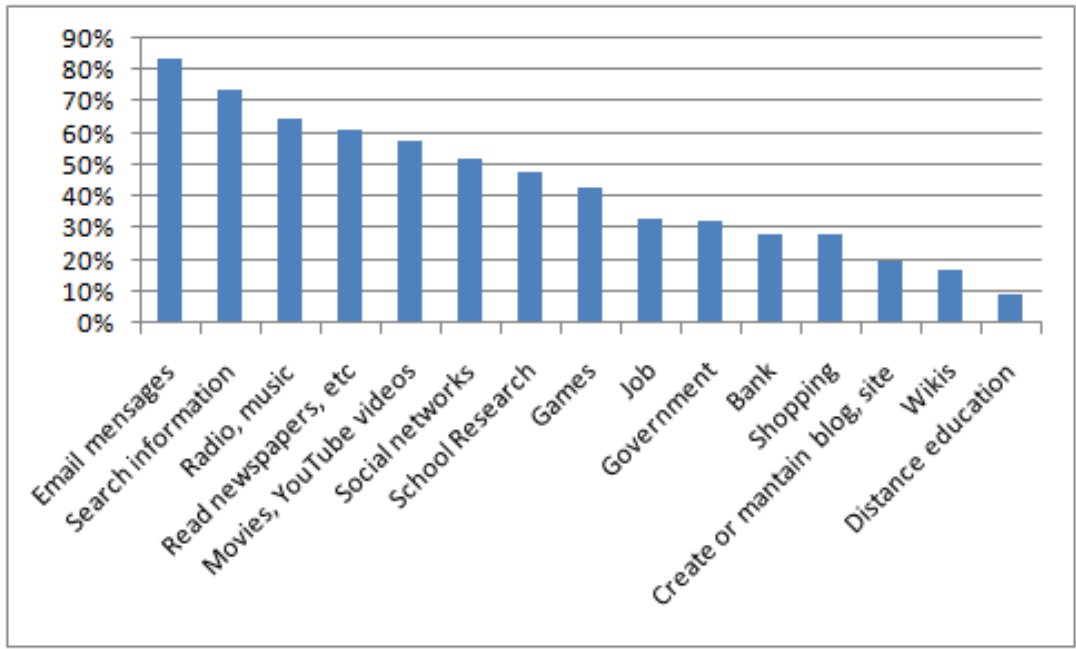

Figure 1. Brazilians' activities with the computer (Source: INAF Brazil 2001-2011).

Exchanging messages and searching for information are the most common activities carried out by computer's users in Brazil. Other popular activities are related to leisure and entertainment, such as listening to music, reading newspapers, watching movies and taking part in social networks. Half of the population who use computers use it for school research and to play games. That also means that the Brazilian population uses computers to learn, although very few of those who access the Internet use it for distance education.

Actions related to the professional universe, such as work, bank transactions, using government websites, and purchasing items, occur in a slightly smaller percentage. Content production, such as collaborating in wikis, creating and maintaining websites and blogs, are not frequent actions. These are content production activities that are time consuming and require a fair expertise in the production and dissemination of texts.

All these activities require users to deal with multimodal and hypertextual environments, which, according to the results of PISA, present information that is notoriously difficult to grasp for Brazilian students. Notably, the 2006 PISA results detected that Brazilian students are not good at 
- building a response considering information from various parts of the text;

- making inferences of various kinds;

dealing with unfamiliar texts genres;

- dealing with non-continuous texts (graphs, tables and forms, for simple examples).

These are crucial skills for reading print and digital texts. Data from PISA 2012 lead us to believe that the stagnation of these skills is, at least in part, responsible for the results of Brazilian students in reading in digital environments, which are worse than their results related to printed texts. As shown in Figure 2, our students struggles more when dealing with texts in digital environments than in print. Part of this difference can be explained by the students' lack of familiarity with the presentation of documents in this environment and with the navigation and reading skills they require.

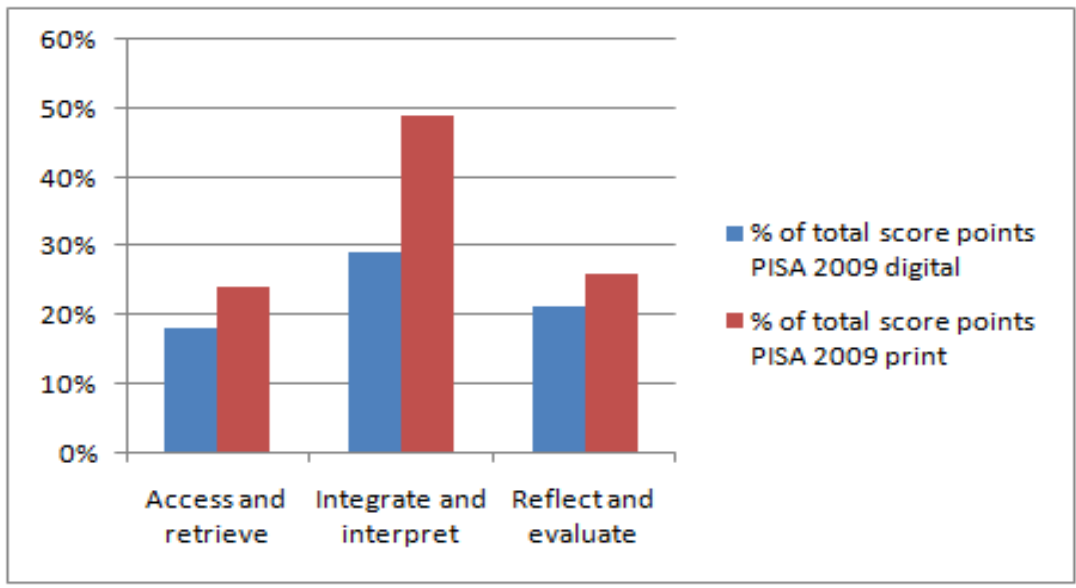

Figure 2. Distribution of score points in digital and print reading assessments by aspect (Source: PISA 2009 Results, 73)

In addition to the lack of Internet access, we believe that students' deficiency in reading skills, already detected in 2006, has contributed to their performance in tasks involving digital technologies, generating lower results than those achieved in tasks involving printed texts.

Both the results of internal research and the results of PISA have con-

International Journal of Transmedia Literacy - 3 - December 2017

http: //www.ledonline.it/transmedialiteracy - Online ISSN 2465-2261 - Print ISSN 2465-227X 
verged towards the need for improvements of the Brazilian educational system, since a large part of the population, and not only students, still have a long way to go for build a stable and durable literacy. The convergence of media makes this process even more complex.

A reaction to the results of the research on ICTs and education is very much needed. Effective public policies - which are very few or are interrupted throughout the decades of our social, political and educational history - are urgent.

\section{ICTS AND SCHOOL IN BRAZIL: SOME INVESTIGATION ABOUT READING AND PRODUCING TEXTS}

For at least three decades, much research has been done and many papers have been published on the concept of literacy. In the last twenty years, this notion has been affected by the introduction of digital technologies into our social practices, which has brought changes in our ways of thinking and doing research on literacy.

For at least twenty years, research connecting ICTs and teaching in Brazil has been conducted. A large percentage of this work aims at understanding and even finding solutions to school issues related to the use of digital technologies. The social use of mobile phones, for example, has triggered research on the possibilities for educational uses of these devices, although their use in schools is currently prohibited, by law, in many Brazilian states.

We mention here, for instance, some recent studies that deal with digital technologies, literacy and education in Brazil. The aspects addressed are usually related to the devices and interfaces that we use more often, but which still do not integrate the set of educational devices in most of the Brazilian schools, whether public or private.

Several studies have been developed in the field of linguistics, especially in a recent national post-graduation program for teachers' development, called ProfLetras ${ }^{2}$. Among hundreds of studies, we take as examples

${ }^{2}$ ProfLetras is a post graduation course that aims at training elementary school Portuguese teachers throughout the country. Some goals of this program include preparing the teachers to deal with multiliteracy, demanded by internet and a globalized world; and qualify teachers to develop students' multiple communicative skills both in online and offline en-

International Journal of Transmedia Literacy - 3 - December 2017

http: //www.ledonline.it/transmedialiteracy - Online ISSN 2465-2261 - Print ISSN 2465-227X 
the research developed by Ambrózio (2016), Gomes (2016), Santos (2015), Souza (2016), Ramos (2016). These studies consist if reports of teachers that create projects using ICTs with their elementary and high school students in Brazil.

Ambrózio (2016) presents an intervention project using Facebook with elementary school students. It is a research that aims at improving reading and writing skills among students, but mainly reveals great problems related to infrastructure and connectivity in Brazilian schools, which has negative impacts on the teachers' work. Ambrózio raises other relevant issues such as the quantity and the quality of information that young people are exposed to, besides the fact that they rarely produce texts or share their own material.

Along the same line we find the studies developed by Gomes (2016), demanding the use mobile phones in classroom activities, Santos (2015), who worked on the production of hyper narratives, Souza (2016), who concentrates on processes of gamification in classes of textual production, and Ramos (2016), with his intervention project on personal reports. In all these cases, research was done with students of Brazilian public schools.

Reading and producing multimodal texts and digital genres is always the focus of much research, although these studies demonstrate some difficulties that teachers have to face when working within a digital and multimodal perspective in schools that cannot rely on good technology infrastructures. It is also important to emphasize that literacy, as far as multisemiotic and transmedia texts are concerned, still needs to be better developed for most Brazilian students and teachers.

Although these studies demonstrate that it is possible to involve students in rich and meaningful tasks, which help them to develop relevant reading skills, as well as to produce multimodal texts, these studies show that the lack in schools of valid ICTs infrastructures that allow working with digital devices can still be an impediment to such practices for many teachers. Nevertheless, these results also demonstrate that teacher's autonomy, creativity and proactivity are able to overcome these and other obstacles that hamper work with ICTs.

The lack of good infrastructures is not the only aspect that inhibits activities with digital technologies. Data gathered by Flores (2015), who ana-

vironments. (Ministério da Educação. Coordenação de Aperfeiçoamento de Pessoal de Nível Superior, 2013)

International Journal of Transmedia Literacy - 3 - December 2017

http: //www.ledonline.it/transmedialiteracy - Online ISSN 2465-2261 - Print ISSN 2465-227X 
lyzed test questions used in an elementary school, reveal a resistance of the educational culture that does not value or stimulate the analysis of multimodal aspects of texts and does not stimulate students to establish connections between non-verbal and verbal elements for the construction of possible meanings of the texts.

Another central aspect, today, of reading skills and text production is hypertextuality, which still does not receive the needed attention from our educators. This concept, widely debated in the early 2000s, has been scrutinized in many studies, such as Marcuschi and Xavier (2004), Braga (2004), Araújo and Biasi-Rodrigues (2005), Coscarelli and Ribeiro (2005), Araújo and Dieb (2009), Gomes (2011), Junqueira and Buzato (2013), among others. Our students still find it very difficult to handle information from multiple sources and to deal with information presented in different parts of the same document, as the results of PISA 2009, reinforced in 2012, demonstrate.

\section{CONSIDERATIONS FOR THE FUTURE: INFRASTRUCTURE AND TEACHER EDUCATION}

Although in recent years many authors have shown that aspects related to technological infrastructure (computers, Internet access, broadband, among others) are important and need to be improved, there are also conceptual and ideological aspects that prevent us from developing new literacy-related projects, including digital and media literacy among the Brazilian population. Among these ideological aspect is the fact that we are still a nation without a voice, which consumes much more information than it produces.

The preparation of competent teachers has been taking place slowly, but it is clear that programs like ProfLetras tend to change - for the better - the panorama of elementary schools, granted that this initiative will continue in the upcoming years. Changes in our educational culture are needed, not only related to the incorporation of digital technologies, but also concerning new ways for promoting literacy for the whole Brazilian population.

Effective public policies on infrastructure and technology, strong teacher training projects and the replacement of traditional educational practices with new meaningful ones, will foster better results in the devel- 
opment of literacy, as well as discontinue our status of consumers, improving the insertion of the population in a more balanced and productive dialogue.

\section{REFERENCES}

Abreu, Ana Rosa, Maria Cristina Ribeiro Pereira, Maria Tereza Perez Soares, Neide Nogueira. 1997. Parâmetros curriculares nacionais: Introdução aos parâmetros curriculares nacionais. Secretaria de Educação Fundamental. Brasília: SEC/SEF. URL:http://portal.mec.gov.br/seb/arquivos/pdf/livro01. pdf. Last access November 28, 2016.

Ambrózio, Sandra Regina. 2016. Escrita em meios digitais: uma experiência com Facebook no Ensino Fundamental. Dissertação (mestrado profissional em Letras). PLACE Universidade Federal de Minas Gerais.

Araújo, Júlio César and Messias Holanda Dieb, eds. 2009. Letramentos na web: Gêneros, interação e ensino. Fortaleza: Edições UFC.

Araújo, Júlio César and Bernardete Biasi-Rodrigues, eds. 2005. Interação na internet: Novas formas de usar a linguagem. Rio de Janeiro: Lucerna.

Bolter, Jay David and Richard Grusin. 1999. Remediation: Understanding New Media. Cambridge: MIT Press.

Bonamino, Alicia, Carla Coscarelli and Franco Creso. 2002. "Avaliação e letramento: concepções de aluno letrado subjacentes ao SAEB e ao PISA”. Educação e Sociedade, Campinas 23(81): 91-113. Last access December 14, 2016. http://www.scielo.br/pdf/es/v23n81/13933.pdf.

Braga, Denise Bértoli. 2004. "A comunicação interativa em ambiente hipermídia: as vantagens da hipermodalidade para o aprendizado no meio digital”. In Hipertextos e gêneros digitais: Novas formas de construção de sentido, edited by Luiz Antônio Marcuschi and Antônio Carlos Xavier, 144-162. Rio de Janeiro: Lucerna.

Instituto de Estudos e Pesquisas Educacionais Anísio Teixeira. Inep. 2007. O que é $o$ Saeb? Sistema de Avaliação da Educação Básica. Last Access June 7, 2007. http://www.inep.gov.br/basica/saeb/caracteristicas.htm.

Ministério da Educação. Coordenação de Aperfeiçoamento de Pessoal de Nível Superior. Capes. 2013. Last Access December 11, 2016. http://www. capes.gov.br/educacao-a-distancia/profletras.

Ministério da Educação. Instituto Nacional de Estudos e Pesquisas Educacionais Anísio Teixeira. Inep. 2012. Matriz de Referência do ENEM. Last Access October 15, 2017. http://download.inep.gov.br/educacao_basica/ en- 
em/downloads/2012/matriz_referencia_enem.pdf.

Coscarelli, Carla Viana and Ana Elisa Ribeiro. 2005. Letramento digital: Aspectos sociais e possibilidades pedagógicas. Belo Horizonte: Autêntica.

Flores, Camila Engler. 2015. Compreensão de tirinhas da Mafalda em enunciados de questões de prova. Dissertação (Mestrado em Estudos Linguísticos) Universidade Federal de Minas Gerais. Last access February 11, 2016. http://www.bibliotecadigital.ufmg.br/dspace/handle/1843/MGSSA7MHK5.

Canclíni, Néstor García. 2001. Consumidores e cidadãos: Conflitos multiculturais da globalização. Rio de Janeiro: UFRJ.

Canclíni, Néstor García. 2008. Leitores, espectadores e internautas. São Paulo: Iluminuras. Elleström, Lars, eds. 2009. Media borders, multimodality, and intermediality. New York: Palgrave.

Gomes, Luiz Fernando. 2011. Hipertexto no cotidiano escolar. São Paulo: Cortez.

Gomes, Fabíola A. Romêro. 2016. Letramento digital e informacional de estudantes do ensino médio no uso do telefone celular. Dissertação (mestrado em Estudos de Linguagens). Centro Federal de Educação Tecnológica de Minas Gerais.

Lima, Ana, Vera Masagão Ribeiro and Roberto Catelli Jr. 2016. Indicador de Alfabetismo Funcional. Instituto Paulo Montenegro. 2016. Last access December 13, 2016. https://drive.google.com/file/d/0B5WoZxXFQTCRRW FyakMxOTNyb1k/view.

Jenkins, Henry. 2006. Cultura da convergência. São Paulo: Aleph.

Junqueira, Eduardo S. and Marcelo E. K. Buzato, eds. 2013. New Literacies, New Agencies? A Brazilian Perspective on Mindsets, Digital Practices and Tools for Social Action In and Out of School. Nova York: Peter Lang.

Marcuschi, Luiz A. and Antonio C. Xavier. 2004. Hipertexto e gêneros digitais. Rio de Janeiro: Lucerna.

Ministério da Educação. Instituto Nacional de Estudos e Pesquisas Educacionais Anísio Teixeira. Inep. 2008. Resultados nacionais - Pisa 2006: Programa Internacional de Avaliação de Alunos (Pisa) / Instituto Nacional de Estudos e Pesquisas Educacionais. Brasília: O Instituto.

OECD. 2011. PISA 2009 Results: Students on Line: Digital Technologies and Performance (Volume VI). Last access January 11, 2016. http://dx.doi. org/10.1787/9789264112995-en.

OECD. 2012. Relatório Nacional PISA 2012: Resultados Brasileiros. Last access December 5, 2016. http://download.inep.gov.br/acoes_internacionais/ pisa/ resultados/2014/relatorio_nacional_pisa_2012_resultados_brasileiros. pdf. 
Ramos, Adriana Mendes. 2016. Relato pessoal: Uma interface entre o letramento e a tecnologia. Dissertação (mestrado profissional em Letras). Universidade Estadual de Montes Claros.

Rojo, Roxane and Eduardo Almeida. 2012. Multiletramentos na escola. São Paulo: Parábola.

Santos, Marcos Celírio. 2015. Entre contos e hipercontos: Uma proposta de trabalho integrado para o desenvolvimento dos multiletramentos. Dissertação. (Mestrado Profissional em Letras). Faculdade de Letras, Universidade Federal de Minas Gerais, Belo Horizonte.

Souza, Rosângela S. dos Santos. 2016. Gamificação: Contribuição para a produção de textos narrativos. Dissertação (mestrado profissional em Letras). Universidade Estadual de Montes Claros.

Xavier, Antônio C. 2002. O bipertexto na sociedade da informação: A constituição do modo de enunciação digital. Tese (Doutorado em Linguística). IEL, Uninversidade Estadual de Campinas. 
